\title{
THE ROLE OF MATHEMATICAL REPRESENTATION AND DISPOSITION IN IMPROVING STUDENTS' MATHEMATICAL POWER
}

\author{
Imam Kusmaryono $^{1}$, Hardi Suyitno ${ }^{2}$ and Dwijanto ${ }^{3}$ \\ ${ }^{1}$ Sultan Agung Islamic University, Semarang, Indonesia \\ ${ }^{2,3}$ Mathematics Education Department, Semarang State University, Indonesia \\ kusmaryono@unissula.ac.id,
}

\begin{abstract}
The success of students in problem solving is highly dependent on the ability of students representing each developmental problems and a higher representation influenced by other representations. The aim of research to uncover and describe the capabilities and dispositions mathematical representation based on the students' mathematical power. The subjects were students (prospective teachers of mathematics) academic year 2015/2016 Mathematics Education Department, Sultan Agung Islamic University. The numbers of students in this study were 29 students. The data collection technique using a mathematical representation tests, mathematical disposition questionnaires and interviews. The study concluded that the representation is affected by the disposition of the mathematical aspects of a person, through a positive disposition will help increase students' understanding of mathematical concepts. Furthermore, the mathematical representation will improve communication skills, perform conjecture and troubleshooting. In general disposition and mathematical representation was instrumental in enhancing the competence of the students' mathematical power.
\end{abstract}

Keywords: disposition, representations, mathematical power

\begin{abstract}
ABSTRAK
Keberhasilan siswa dalam pemecahan masalah sangat tergantung pada kemampuan merepresentasikan masalah dan setiap perkembangan representasi yang lebih tinggi dipengaruhi oleh representasi lain. Tujuan penelitian untuk mengungkap dan menggambarkan kemampuan representasi dan disposisi matematis berdasarkan daya matematika siswa. Subjek penelitian ini adalah mahasiswa calon guru matematika tahun akademik 2015/2016, Prodi Pendidikan Matematika Universitas Islam Sultan Agung. Jumlah mahasiswa dalam penelitian ini adalah 29 orang. Teknik pengumpulan data menggunakan tes representasi matematika, kuesioner disposisi matematika dan wawancara. Studi ini menyimpulkan bahwa representasi dipengaruhi oleh aspek disposisi matematika dari seseorang, melalui disposisi positif akan membantu meningkatkan pemahaman siswa tentang konsep-konsep matematika. Selanjutnya, representasi matematis akan meningkatkan kemampuan komunikasi, melakukan dugaan dan pemecahan masalah. Secara umum disposisi dan representasi matematis berperan penting dalam peningkatan kompetensi daya matematika siswa.
\end{abstract}

Kata kunci: disposisi, representasi, daya matematika

\section{Introduction}

Learning math is basically learning about the reason. Learning math is a learning activity or activity that emphasizes the aspects of reasoning. On learning of mathematics in schools students are trained to do reasoning, meaning that learning should involve students actively 
to reason, strengthen their understanding of mathematical concepts (Stacey, 2006). In the process of reasoning students will construct their own knowledge -stage thinking students.

Learning math is not just convey information, showing the formula and insists on the procedure of processing a matter of course, but teachers act as mediators and facilitators and assist students through the creation of conducive learning so that students actively and continuously construct his own knowledge to reason. Students not a photocopy of adults, what to think or rationalized by adults (teachers) can not directly forcibly transferred from the teacher to the student. Each student has a different way in the process of reasoning to construct knowledge, in other words the students had different levels of mathematical representation, between students and teachers and between students and other students. With regard this, teachers are expected to reduce plantings doctrines in mathematics. Problem-solving solutions no longer have to follow the procedure and should be done as exemplified by the teacher, because it would be possible settlement of problem solving can be through a variety of mathematical representations that can bring critical attitude and creative students.
Brenner (Neria \& Amit, 2004) states that the success of students in problem solving is dependent upon the ability of students to represent a problem, such as constructing and using mathematical representations in the form of graphs, words, equations, tables and images or manipulation of symbols mathematical more. Hwang, et.al (2007), in a study entitled influence the ability of multiple representations and creativity to solving mathematical problems using multimedia whiteboard system. Research results showed that scores of students who use the formula better representation of the student using verbal representations and graphic images or symbols.

NCTM (2000) and Sumarmo (2012) states that the representations are expressions of ideas or the ideas of mathematics that displayed the students in their efforts to seek a solution of the problems being faced as a result of the interpretation of the mind. The idea of a mathematical representation in Indonesia has been included in goal of learning mathematics in schools in Regulation No. 23 of 2006 (Depdiknas, 2007). The survey results Trends International Mathematics and Science Study (TIMSS) in 2011 showed that the ability of students' mathematical representation of Indonesia is still low. Indonesia is ranked 
38 of 42 countries surveyed. This is because students in Indonesia are less accustomed to solve problems with such characteristics questions in TIMSS. Learning mathematics at school is not giving students the opportunity to present their own representation. Students are only used to do the questions are routine and imitate the teacher in solving the problem, so the ability of students to develop their ideas and express them in various forms of representation are underdeveloped. As a result, the ability of students' mathematical representation is low. Learning monotonous and conventional as it only focused on lowlevel thinking skills.

Conventional learning like this, certainly not in accordance with the objectives set curriculum of mathematics education in primary and secondary schools. The purpose of learning mathematics in primary education and secondary education is to prepare students to be able to face changing circumstances in life and in the world is always evolving, through the practice of acting on the basis of thinking logically, rationally, critically, careful, honest, efficient and effective. In addition, students are expected to use mathematics and mindset of mathematics in everyday life, and in studying various scientific emphasizes on the structuring of reason and higher level thinking and forming student attitudes and skills in the application of mathematics. Ability and skill mathematical representation is also indispensable for students and teachers in the learning of mathematics. Lack of ability and mathematical skills of the students can lead students toward mathematics disposition will also decrease.

In mathematics, the disposition is one component that is essential for students (college students) for students accustomed to getting issues that require a positive attitude, desire, passion, and persistence as well as challenges to complete. Without a good mathematical disposition then students cannot achieve competence or mathematical prowess as expected. Disposition is defined as a tendency of students or individual students in mathematical looked positively or negatively (Kilpatric, Findel \& Swaford, 2001). In simple, mathematical disposition can be regarded as the attitude, interest and motivation toward mathematics. A large study has proven that the disposition has a strong positive association with cognitive ability. Hudiono (2005) in his research on mathematics learning in junior high school teacher concluded that the lack of knowledge and habits students learn in the classroom in a conventional way has 
not been possible to develop student representation power optimally. Asikin and Junaedi (2013), found the disposition has a strong positive relationship with solving ability mathematics at the primary level. Likewise, the effect of handling the disposition has a strong relationship with the mathematical skills of students of junior high schools (Syaban, 2009).

In addition to low-level mathematical thinking and high, students also need to be trained to think advanced, the students are trained to construct and create your own picture mathematical definition. Through constructing and find definitions or concepts in mathematics students are expected to develop other mathematical abilities, in terms NCTM the capability in question was referred to as a mathematical power process.

Basically, every student has the ability and potential in him. Including the mathematical power, but mathematical power levels that each student is different (Kusmaryono, 2015). After reviewing the relevant literature, in this study the mathematical power is defined as "the belief of individuals to use knowledge of the conceptual and operational within the framework of the content specified in a situation to solve problems using reasoning, communication and connection together" (Mandaci \&
Baki,2010). Dimensional mathematical representation of the power of mathematics can be presented as shown below.

In Figure 1 below, it is understood, that the expected product are obtained when students utilize their knowledge of mathematics with math skills together within the framework of the specified contents are indicators of Mathematical Power.

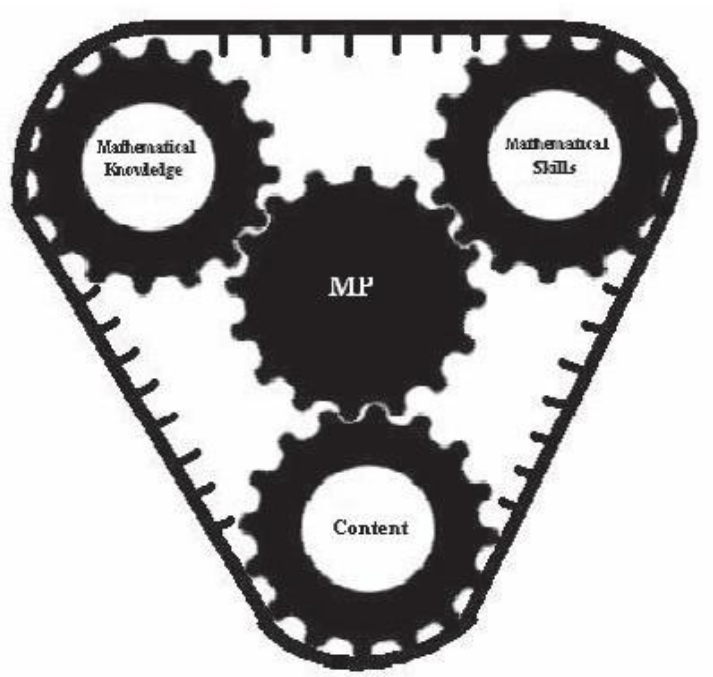

Figure 1. Mathematical Representation of Mathematical Power Dimensions (MP)

Do math including integrated and dynamic activities, such as discovery, exploration, conjecture, and understand the evidence. In this case it is clear that this attitude, the general target primary and secondary education programs related to learning mathematics throughout the world is to develop Mathematical Power. 
NCTM (2000) states, the mathematical power include the ability to explore, build conjecture; and give logical reasons; the ability to solve the problem of non-routine; communicate ideas about mathematics and using mathematics as a communication tool; connect ideas in mathematics, between mathematics and other intellectual activities. As an implication, the mathematical power is an ability that needs to be owned by students who studied mathematics at each school level, as has been recommended by the NCTM (Sharon L., Charlene. E. \& Denisse, R. 1997). Therefore how mathematics should be implemented to cultivate the students' mathematical power (Kusmaryono, 2016).

The results of the study Dharma et. al. (2013) showed that the realistic mathematics education more effective in improving understanding of the concept and students' mathematical power. It is important to note that in each of their learning (students) need to be encouraged to discuss their processes in order to improve understanding, gain new insights and can communicate their ideas (Thompson, 2008). The idea is based on the fact that mathematics is more than a collection of concepts and skills that must be mastered. This includes methods of investigation and reasoning, communication, and the notion of context. Mathematical power also served to spur the success of the appreciation of the complexity of the students in the interdisciplinary study (Mueller and Lourdes, 2005). Each individual involves the development of personal trust (NCTM, 1989; Baroody, 2000). In the principles and standards of school mathematics (NCTM), namely the principle of learning (Learning Principles), emphasizing the students' activity to build new knowledge from experience and knowledge, so that students must learn to math with a true understanding. Bodner (1986) states that knowledge is constructed by the learner with trying to regulate existing experience in previous mental structure. Thus, mathematics is a process of acquiring knowledge that is created or performed by the students themselves through the transformation of individual experience.

We know that, in mathematical knowledge that leads to mathematical power, requires the ability to use information to think creatively and to formulate, solve, and reflect critically on issues (NCTM.2000). Consistent with constructivist theories and supporting evidence, NCTM (1989; 1991) has recommended shifting from traditional instructional approaches toward a better 
approach encourages children math power. Aspects of capabilities contained in the mathematical power is part of mathematical high-level thinking skills. Therefore develop students' mathematical power starts from the level of young people has become an important goal of the present study of mathematics (Philips \& Anderson, 1993; NCTM, 1989; Diezman, 2005).

The assessment of students with a mathematical measure of how much information they have to enter their level of ability and willingness to use, implement, and communicate that information (Signe, 2005). Marjolijn.P, et.al. (2009), confirmed that the suspect with the true reason is the mathematical thinking process using Mathematical Power. The assessment of mathematics should examine the extent to which students have been integrated and make informed, whether they can apply them to situations that require reasoning, and they can use math to communicate ideas (NCTM, 2000). On this basis, research must be conducted to determine the role of representation and disposition of mathematics students to improve students' mathematical power on mathematics problems solving.

\section{Research Methods}

The study was conducted with survey approach and descriptive method. The purpose of study was to look for information in a way to reveal and describe the capabilities and dispositions mathematical representation based on the power of mathematics students. The research subject chosen was a student (prospective teachers of mathematics) odd semester academic year 2015/2016 on Mathematics Education Department, Sultan Agung Islamic University. The numbers of students in this study were 29 students. The data collection technique was performed under measurement techniques in the form of mathematical representation ability tests, questionnaires regarding the disposition of mathematical and semi-structured interviews. The results of tests the ability of a mathematical representation is expressed in the form of scores and classified based on the level of students. Here is presented a mathematical representation indicator.

Table 1. Indicators Mathematical

Representation

\begin{tabular}{|l|l|l|}
\hline No. & Representation & \multicolumn{1}{|c|}{ Forms of operational } \\
\hline 1 & $\begin{array}{l}\text { Visual } \\
\text { representation }\end{array}$ & $\begin{array}{l}\text { Using visual representations to } \\
\text { solve problems } \\
\text { Make a picture to clarify issues } \\
\text { and facilitate the results }\end{array}$ \\
\hline 2 & $\begin{array}{l}\text { Representation } \\
\text { or } \\
\text { mathematical } \\
\text { expression }\end{array}$ & $\begin{array}{l}\text { Creating a mathematical model } \\
\text { of the equation or other } \\
\text { representation given } \\
\text { Solving problems involving } \\
\text { mathematical expression }\end{array}$ \\
\hline 3 & $\begin{array}{l}\text { Words or } \\
\text { written text }\end{array}$ & $\begin{array}{l}\text { Writing interpretation of a } \\
\text { representation } \\
\text { Answering questions by using } \\
\text { words or written text }\end{array}$ \\
\hline
\end{tabular}


Acquisition of data to measure the ability of a mathematical representation, then performed the scoring as follows:

Table 2. Rubric Scoring Ability

Mathematical Representation

\begin{tabular}{|c|l|}
\hline Score & \multicolumn{1}{|c|}{\begin{tabular}{c}
\multicolumn{1}{c}{ Explanation ability mathematical } \\
representation
\end{tabular}} \\
\hline 0 & $\begin{array}{l}\text { No answer, if there is only shows the lack of } \\
\text { knowledge about the concept that the } \\
\text { information provided does not mean anything }\end{array}$ \\
\hline 1 & $\begin{array}{l}\text { only there is an explanation of what is known, } \\
\text { what is being asked only }\end{array}$ \\
\hline 2 & $\begin{array}{l}\text { There are very few explanations, diagrams or } \\
\text { drawings and mathematical models are correct }\end{array}$ \\
\hline 3 & $\begin{array}{l}\text { Mathematically plausible explanation, but } \\
\text { only partially complete and correct, diagram } \\
\text { depicts the picture is less complete and } \\
\text { correct, while finding a mathematical model } \\
\text { correctly, but wrong in getting solutions }\end{array}$ \\
\hline 5 & $\begin{array}{l}\text { Mathematically plausible explanation and } \\
\text { clear, though not arranged logically or there is } \\
\text { a little mistake, depicting diagrams or } \\
\text { drawings are complete and correct and find a } \\
\text { mathematical model correctly, then perform } \\
\text { calculations or get in a logical and complete } \\
\text { solutions }\end{array}$ \\
\hline 5 & $\begin{array}{l}\text { Mathematically plausible explanation and } \\
\text { clear, arranged logically or not there is an } \\
\text { error, depicts diagrams or drawings are } \\
\text { complete and correct and find a mathematical } \\
\text { model correctly, then perform calculations or } \\
\text { get in a logical and complete solutions }\end{array}$ \\
\hline
\end{tabular}

Furthermore, for the purpose of clarifying the mathematical representation of the quality of students, the score changed in terms of percentage and is categorized as follows:

Table 3. Quality of Mathematical

Representation

\begin{tabular}{cc}
\hline $\begin{array}{c}\text { Score Value } \\
\text { (In percentage ) }\end{array}$ & $\begin{array}{c}\text { Quality } \\
\text { Ability } \\
\text { Representation }\end{array}$ \\
\hline $90 \% \leq$ Value $\leq 100 \%$ & very good \\
$75 \% \leq$ Value $<90 \%$ & Good \\
$55 \% \leq$ Value $<75 \%$ & Enough \\
$40 \% \leq$ Value $<55 \%$ & Less \\
Value $<40 \%$ & Very less \\
\hline
\end{tabular}

Questionnaires given to students at the beginning of the study, a questionnaire technique is used to obtain data on student mathematical disposition, consisting of: 12 positive statements and 12 negative statement following the disposition indicator mathematically as follows: (a) Confidence in solving mathematical problems;

Communicating mathematical ideas and try an alternative method of resolving the conflict; (c) persistent in math homework; (d) Interested, curious and creative in mathematics activities; (e) to appreciate the role of mathematical tools and languages; (f) Share your opinion with other people .

This section presents the questionnaire scoring criteria mathematical dispositions that are classified following the table below:

Table 4. Criteria Level Mathematical Dispositions

\begin{tabular}{cc}
\hline $\begin{array}{c}\text { Range of Scores } \\
(\%)\end{array}$ & $\begin{array}{c}\text { Criteria Disposition } \\
\text { Mathematically }\end{array}$ \\
\hline 76 to 100 & High \\
51 to 75 & Enough \\
26 to 50 & Low \\
0 to 25 & Very Low \\
\hline
\end{tabular}

After the students take the test the ability of mathematical representations, interviews were conducted with the aim to obtain in-depth information about the mathematical representation, disposition and power of mathematics and the difficulties experienced by students in the test item .

\section{Result and Discussion}


The results of tests the ability of a mathematical representation of each student can be classified by aspects of mathematical representation (enactive, iconic, symbolic), the level of students' abilities and inclinations mathematical power students are presented in the following table.

Table 5. Results of Student Mathematical Representation

\begin{tabular}{|l|l|l|l|l|}
\hline \multirow{2}{*}{$\begin{array}{l}\text { Ability } \\
\text { student }\end{array}$} & \multicolumn{2}{|l|}{$\begin{array}{l}\text { Aspects of Mathematical } \\
\text { Representation }\end{array}$} & \multirow{2}{*}{$\begin{array}{l}\text { Mathemati } \\
\text { cal Power } \\
\text { (MP) }\end{array}$} \\
\cline { 2 - 4 } & Enactive & Iconic & Symbolic & \\
\hline High & --- & High & Very High & MP - High \\
\hline Medium & --- & High & High & MP - High \\
\hline Low & Medium & Low & Medium & $\begin{array}{l}\text { MP - } \\
\text { Medium }\end{array}$ \\
\hline
\end{tabular}

Achievement indicators mathematical disposition through a questionnaire given to students, obtained the following data.

Table 6. Disposition Mathematical Achievement Indicators

\begin{tabular}{lccc}
\hline $\begin{array}{l}\text { Ability } \\
\text { student }\end{array}$ & $\begin{array}{c}\text { Total } \\
\text { Score }\end{array}$ & Percentage & Criteria \\
\hline $\begin{array}{l}\text { Top group } \\
\text { ( high ) }\end{array}$ & 364 & $75 \%$ & High \\
$\begin{array}{l}\text { Central } \\
\text { Group } \\
\text { ( medium ) }\end{array}$ & 1.182 & $77 \%$ & High \\
$\begin{array}{l}\text { Bottom } \\
\text { group (low ) } \\
\text { Total Score }\end{array}$ & 583 & $76 \%$ & High \\
\hline
\end{tabular}

Based on the test results in Table 4.1 and 4.2, the achievement indicators questionnaire and analysis result disposition mathematical research, it is known that all student ability level low, medium and high overall had an average high mathematical disposition. The ability of representation in terms of the ability of students the results are different. Students with a high capacity amounted to 5 students, mathematical representation of test results on the student group is obtained 1 students were in the category of iconic high and 4 students were in the category of very high symbolic. While the average power of mathematics (mathematical power) is at a high level.

In the group of top level mathematical power reaches a high level, this seems on the ability of students in terms of preparing a conjecture, investigation and exploration and come to understand the evidence. On top of this group indicates that the disposition of high mathematical achievement that indicator amounted to $75 \%$ has an important role in the mathematical representation. Based on the results of interviews with students, disposition and student high mathematical representation can help increase power mathematical ability of students.

Students with moderate ability dispositions totaling 16 students have high mathematical achievement indicator with a score of $77 \%$. The results of tests on a mathematical representation of this middle group of students obtained 10 students were in the category of iconic high and 6 students were in the category 
of high symbolic. While the average power of mathematics (mathematical power) is at a high level. Students in the group of top and middle (highly skilled and are) no longer depends on thinking enactive but is in conformity with the cognitive development that is iconic and symbolic thinking.

Students with low ability were 8 students have a high mathematical disposition with a score of $76 \%$ achievement indicator. The test results on student mathematical representation under the group acquired two students were in the category enactive, two students have low iconic representation and two students were in the category of symbolic medium. For the average ability of mathematics (mathematical power) are at moderate levels. At the bottom of this group, two students have engaged in representing the shape of the iconic and symbolic. Students cognitive development is still dependent on something real (iconic). Of course, at this stage the student must immediately release the ways of thinking that are iconic, because science is accepted at the college level are more iconic and symbolic.

Student (prospective teachers of mathematics education) at the time of the interview revealed that Bony and Nurul has a mathematical disposition more productive than David and Siti. Interestingly, when the students were asked to recall the experience of the importance of mathematics in life, they consistently choose the experience that happened when they were in elementary school. His interest in mathematics in primary school classrooms may serve to reinforce the idea that mathematical disposition formed at the beginning of one's school career. While David and Siti, saw mathematics as a positive disposition, especially as a way to create a bond between friends experiences for sharing and discussing, so that adds to the spirit of learning mathematics. It can be said that the experience of the individual person will establish a mathematical disposition someone (Feldhaus, 2014).

The tendency of a mathematical representation of students in this study is a mathematical representation of iconic and symbolic aspects of the most widely selected students in a math problem. Based on the results of student mathematical disposition questionnaire both at the top, middle and bottom have a high mathematical disposition. Students are required to be able to analyze the problem, collect the appropriate information and connect with their ideas, and then present their thoughts in the form of images or mathematical expressions, and finally found the 
solution of the given problem. Such activities can improve students' mathematical representation.

Based on the results of interviews with students, disposition and student high mathematical representation can help increase power mathematical ability of students. This is consistent with the statement Hudiono (2005) states that "In view of Bruner, enactive, iconic and symbolic, related to the mental development of a person, and any developments higher representation influenced by other representations."

\section{Conclusion}

Based on the test results of a mathematical representation, disposition questionnaires and interviews with student teachers of mathematics education, disposition and student high mathematical representation can help increase power mathematical ability of students. This parallels the view Bruner (Hudiono, 2005) that the representation (enactive, iconic, symbolic) are associated with a person's mental development, and any developments higher representation influenced by other representations. "

Representation also indirectly influenced by the mathematical aspects of a person's disposition, through positive disposition will help increase students' understanding of mathematical concepts. Furthermore, the mathematical representation will improve communication skills, perform conjecture and troubleshooting. In general disposition and mathematical representation was instrumental in enhancing the competence of mathematical power of students. Therefore, teachers or lecturers need to find the right way to be a member of space to expand the representation of students in mathematics learning by interactive learning and problem-based.

\section{Reference}

Asikin, Mohammad. Dan Junaedi, Iwan. 2013. Kemampuan Komunikasi Matematika Siswa SMP Dalam Setting Pembelajaran RME (Realistic Mathematics Education)". Unnes Journal of Mathematics Education Research. Vol. 2(1):pp. 203-207

Baroody. J Arthur.2000. Does Mathematics Instruction for 3- to 5Year Olds Really Make Sense? Research in Review article for Young Children. Journal of the National Association for the Education of Young Children. University of Illinois at UrbanaChampaign. 
Bodner, G.M. 1986. Constructivism: A theory of knowlwdge. Journal of Chemical Education. Volume 63 (10).

Depdiknas. 2007. Kajian Kebijakan Kurikulum Mata Pelajaran Matematika. Jakarta: Depdiknas Badan Penelitian dan Pengembangan Pusat Kurikulum.

Dharma I. N., \& Sadra, I. W.2013. Pengaruh Pendidikan Matematika Realistik Terhadap Pemahaman Konsep dan Daya Matematika Di Tinjau Dari Pengetahuan Awal Siswa SMP Nasional Plus Jembatan Budaya. Jurnal Pendidikan Matematika, 2. pasca.undiksha.ac.id

Diezmann, C. M.2009. Challenging mathematically gifted primary students. Australiasian Journal of Gifted Education, 14(1), 2005. 5057. From Retrieved 2 April 2009.

Fadillah, Syarifah Alhadad.2010. Upgrading Multiple Representation Mathematically, Mathematical Problem Solving and Self Esteem junior high school students through the Learning Approach Open Ended. Disertasi UPI. Bandung.

Feldhaus, C. A.2010. What are they thinking? An examination of the mathematical disposition of preservice elementary school teachers. Paper presented at the American Mathematical SocietyMathematics Association of America Joint Mathematics Meetings, San Francisco, CA.

Feldhaus, C.A. 2014. How Pre Service Elementary School Teachers' Mathematical Dispositions are Influenced by School Mathematics. University of Northern Iowa USA. American International Journal of Research Kontemporer. 4(6)..91 97

Hudiono, Bambang. 2005. Peran Pembelajaran Diskursus Multi Representasi Terhadap Pengembangan Kemampuan Matematik dan Daya Representasi pada Siswa SLTP. Disertasi UPI Bandung. .

Hwang, et al. 2000. Multiple Representation Skills and Creativity Effects on Mathematical Problem Solving using a Multimedia Whiteboard System. Educational Technology \& Society. 10(2). pp. 191-212.

Kusmaryono, Imam \& Suyitno, Hardi. 2015. Mathematical Power's Description of Students in Grade 4th Based on The Theory of The Role ... (Imam Kusmaryono) 
Constructivism. International

Journal of Education and Research

Australia. Volume 3 No. 2. 2015.

Pp. 299 - 310, Februari 2015.

ISSN: 2201-6333 (Print) ISSN:

2201-6740 (Online). http://

www.ijern.com

Kusmaryono, Imam \& Suyitno, Hardi. 2016. The Effect of Constructivist Learning Using Scientific Approach on Mathematical Power and Conceptual Understanding of Elementary Schools Grade IV. Journal of Physics: Conference $\begin{array}{llll}\text { Series } & 693 & \text { (2016) } & 012019\end{array}$ Published under licence by IOP Publishing Ltd. Online 7 Maret 2016.

Availabel:

iopscience.org/1742-6596/693/1.

Mandaci, Sahin and Baki, Adnan, 2010.

A New Model to Assess Mathematical Power. Procedia Social and Behavioral Sciences Journal Vol. 9. 2010. Elsevier Ltd. Available online: http: www.sciencedirect.com/.../S1877042810024419

Marjolijn Peltenburg, et.al. 2009. "Mathematical power of specialneeds pupils: AnICT-based dynamic assessment format to reveal weak pupils' learning potential." British Journal of
Educational Technology. 40(09) p.273-284 doi:10.1111/j.14678535.2008.00917.x

Mueller, Mary and Lourdes Z. Mitchel. 2005. Building Mathematical Power: Why Change is So Difficult. International Journal for mathematics teaching and learning. ISSN. 1473-0111. This journal is indexed in both $\underline{\text { ERIC }}$ and EBSCO. www.cimt.plymouth. ac.uk/journal/mueller.pdf

National Council of Teachers of Mathematics (NCTM). 1989. Curriculum and Evaluation Standards for School Mathematics: A Vision of Mathematical Power and Aprpreciation for All. Reston. VA: NCTM.

National Council of Teachers of Mathematics (NCTM). Professional Standards for Teaching Mathematics.Reston. VA: NCTM. 1991

National Council of Teachers of Mathematics' (NCTM). 2000. Principles and Standards for School Mathematics, Evaluation: Standard K-4 Mathematical Power. Reston. VA: NCTM.

Neria, D. \& Amit, M. 2004. Students Preference of Non-Algebraic 
Representations in Mathematical Communication. Proceedings of the 28th Conference of the International Group for the Psychology of Mathematical Education. Vol. 3, 2004. pp. $409-$ 416.

Phillips E. \& Ann Anderson. 1993. Article. "Developing mathematical power: A case study." Journal of Early Development and Care. 96(1),1993. Pp. 135-146. DOI: 10.1080/0300443930960111.

Published online: 07 July 2006. Available at.

Sharon L. Senk, Charlene E. Beckmann, and Denisse R. Thompson. 1997. Assessment and Grading in High School Mathematics Classrooms. Journal for Research in Mathematics Education. Available at: http://math.coe.uga.edu/olive /...JRME1997-03-187a.p

Signe, E. Kastberg. 2005. Context Matters In Assesing Students Mathematical Power. For the Learning of Mathematics. An International Journal of Mathematics Education. 25 (2), p. 10-16.

Stacey, Kaye. 2005. The place of problem solving in contemporary mathematics curriculum documents. Journal of Mathematical Behavior. 24, pp 341 -350 .

Stacey, Kaye. 2006. what is mathematical thinking and why is it important? . Journal of Mathematical Behavior 24, ww.criced.tsukuba.ac.jp/math/.../Ka ye\%20Stace..2006.

Sumarmo, U. 2012. Pendidikan Karakter Serta Pengembangan Berpikir dan Disposisi Matematika dalam Pembelajaran Matematika. Makalah disajikan pada Seminar Pendidikan Matematika di NTT, 25 Februari 2012

Syaban, $\quad$ Mumun. 2009. Menumbuhkembangkan Daya dan Disposisi Matematis Siswa Sekolah Menengah Atas Melalui Pembelajaran Investigasi. Jurnal Educationist. ISSN. 1907- 8838 Vol. III No. 2 Juli 2009. Hal. 129 236

Thompson, Tony. 2008. Mathematics Teachers'Interpretation of Higher Order Thinking In Bloom Taxonomy, International Electronic Journal of Mathematics Education Volume 3, Number 2, July 2008 tersedia di www.iejme.com The Role ... (Imam Kusmaryono) 
